\title{
First pelagic record of the velvet dogfish Zameus squamulosus (Günther, 1877) (Squaliformes) from the southwestern Indian Ocean and some notes on its regional distribution
}

\author{
Evgeny V. ROMANOV \\ PROSPER Project \\ (Prospection et habitat des grands pélagiques de la ZEE de La Réunion), \\ CAP RUN - ARDA, Magasin $n^{\circ} 10$ - Port Ouest, \\ F-97420 Le Port, île de La Réunion (France) \\ prosper.arda@orange.fr \\ Pascal BACH \\ Institut de Recherche pour le Développement (IRD), \\ UMR 212 Écosystèmes marins exploités, SEMIR, \\ 16, rue Claude Chappe, ZI Développement 2000, \\ F-97420, Le Port, île de La Réunion (France) \\ pascal.bach@ird.fr \\ Sergei T. REBIK \\ Southern Scientific Research Institute \\ of Marine Fisheries and Oceanography (YugNIRO), \\ 2 Sverdlov St., 98300, Kerch, Crimea (Ukraine) \\ rebikst@mail.ru \\ Alexandre LE TURC \\ Blue Planet, 73 chemin Saint Sauveur, \\ F-97432 Ravine des Cabris, île de La Réunion (France) \\ alexandre.leturc@gmail.com \\ Bernard SÉRET \\ Institut de Recherche pour le Développement (IRD), \\ Muséum national d'Histoire naturelle (MNHN), \\ Département Systématique et Évolution, \\ case postale 51, 57 rue Cuvier, F-75231 Paris cedex 05 (France) \\ seret@mnhn.fr
}

Romanov E. V., Bach P., Rebik S. T., Le Turc A. \& Séret B. 2013. - First pelagic record of the velvet dogfish Zameus squamulosus (Günther, 1877) (Squaliformes) from the southwestern Indian Ocean and some notes on its regional distribution. Zoosystema 35 (1): 11-23. http://dx.doi.org/10.5252/z2013n1a2 
KEY WORDS

Elasmobranchii,

benthopelagic shark, deep-water habitat, pelagic occurrence,

SW Indian Ocean, new records.

MOTS CLÉS

Elasmobranchii, requin benthopélagique, habitat profond, occurrence pélagique,

SO océan Indien, nouvelles signalisations.

\begin{abstract}
A pelagic record of a rare deep-water shark, the velvet dogfish Zameus squamulosus (Günther, 1877), is described from the southwestern Indian Ocean. This is the first pelagic record from the western Indian Ocean and the eleventh published record of this species from the entire basin. Together with non-published records from museums and online databases the number of verified Indian Ocean records of this species currently exceeds 50 individuals. Zameus squamulosus is a benthopelagic species usually occurring on the slopes of the continents and in mid-ocean oceanic ridges, between 400 and $1450 \mathrm{~m}$ depth, but it makes rare incursions in open water to the limits of the epipelagic zone.
\end{abstract}

\section{RÉSUMÉ}

Première observation pélagique d'un squale-grogneur velouté, Zameus squamulosus (Günther, 1877) (Squaliformes), de l'océan Indien sud-occidental et quelques notes concernant sa distribution régionale.

La présence en milieu pélagique d'une espèce rare de requin de profondeur, le squale-grogneur velouté Zameus squamulosus (Günther, 1877), est décrite dans le sud-ouest de l'océan Indien. Il s'agit de la première signalisation de cette espèce en milieu pélagique dans l'océan Indien occidental, et de la onzième dans le bassin entier. En comptant les signalisations non publiées à partir des musées et les bases de données en ligne, les signalisations avérées de cette espèce dans l'océan Indien dépassent les 50 individus. Zameus squamulosus est une espèce benthopélagique : elle fréquente habituellement les pentes des continents et les dorsales océaniques, entre 400 et $1450 \mathrm{~m}$ de profondeur; elle effectue aussi de rares incursions en pleine eau, à la limite inférieure de la zone épipélagique.

\section{INTRODUCTION}

The squaloid shark Zameus squamulosus (Günther, 1877 ) is a deep-water species, encountered in the benthic and sometimes in the pelagic environment along continental margins of tropical and temperate waters in the Atlantic and Pacific (Compagno 1984; Wetherbee \& Crow 1996). Its distribution and occurrence in the Indian Ocean are still obscure. Only few published records of $Z$. squamulosus are known from the undersea ridges of the southern tropical Indian Ocean (Scherbachev et al. 1982). Other records, although lacking geo-referencing precision, are attributed to continental slope areas of South Africa, Australia and Java (Indonesia) (Bass et al. 1976; Last \& Stevens 1994, 2009; White et al. 2006). One individual was recently collected at a landing site in Cochin, India (Akhilesh $e t$ al. 2011).

Despite its global distribution, biology and habitat of the velvet dogfish are still poorly known: it is listed as "data deficient" on the IUCN Red List of Threatened Species (Burgess \& Chin 2006). Therefore information presented in this note is important for the understanding of this species' ecology.

Here we describe the first record of $Z$. squamulosus from the pelagic zone of the tropical southwestern Indian Ocean and present a further nine recent records from the demersal environment. We discuss regional species distribution based on: 1) published data; 2) museum collection inventories; and 3) online sources. Finally, we debate the reliability of information from internet portals. 

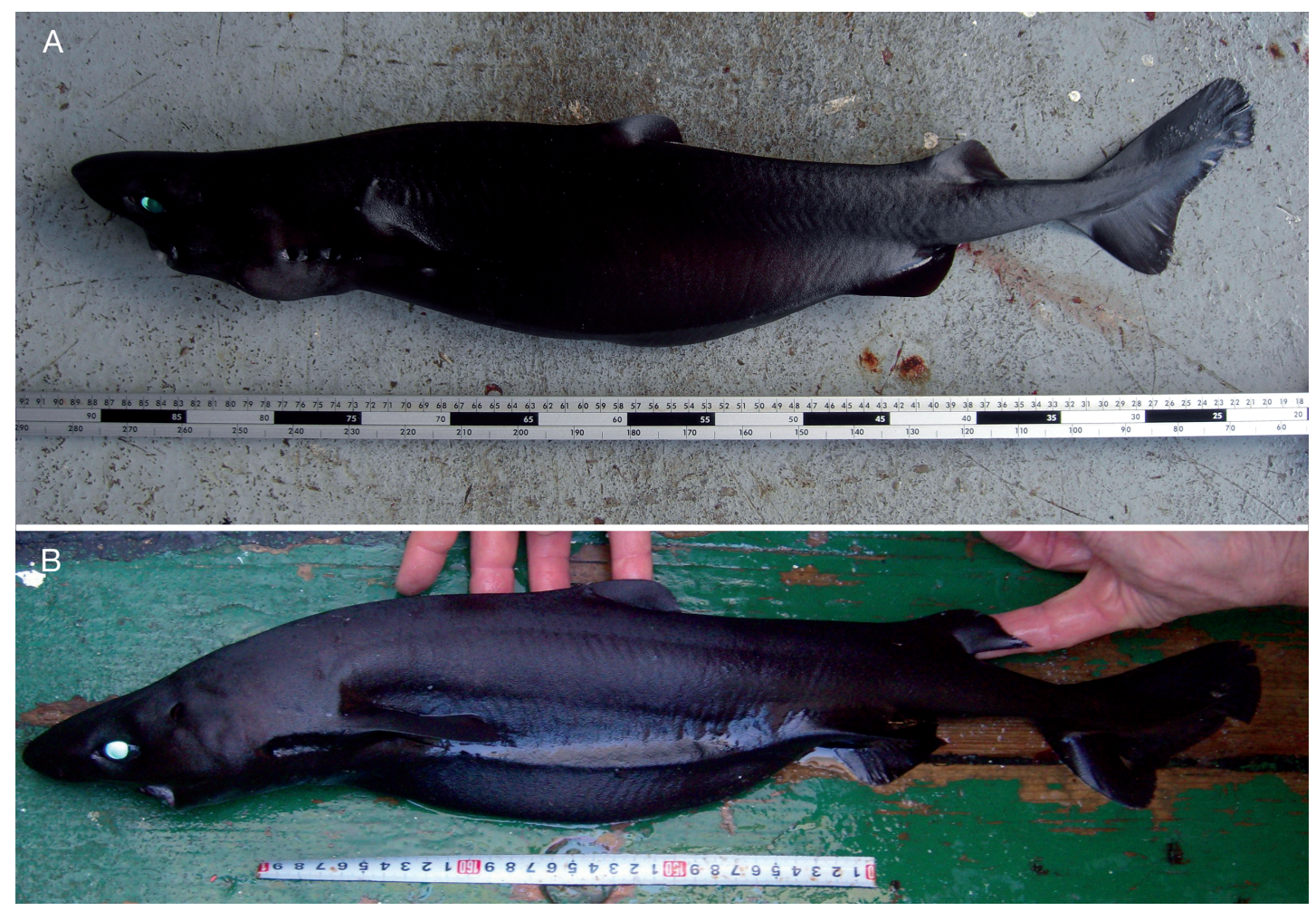

FIG. 1. - Individuals of Zameus squamulosus (Günther, 1877) caught in the pelagic and demersal environment: A, MNHN 2012-0188, female (672 mm TL) caught on a pelagic longline set on 25 May 2011 in the southwestern Indian Ocean (black bar at the ruler is equal to $5 \mathrm{~cm}$ ); B, female caught on a demersal longline set on 5 March 2008 in the southeastern Indian Ocean (see Table 2 for details) (ruler length is $30 \mathrm{~cm}$ ).

\section{MATERIAL AND METHODS}

A female of Zameus squamulosus $(672 \mathrm{~mm}$ total length, TL; $640 \mathrm{~mm}$ fork length, FL) (Fig. 1A) was caught on 25 May 2011 on a tuna longline set by the commercial fishing vessel Fournaise during a research cruise in the framework of the PROSPER Project. E. V. Romanov and A. Le Turc were onboard during the capture, collected accurate fishing and environmental data and preserved the specimen. Approximate capture position $\left(23^{\circ} 17^{\prime} \mathrm{S}, 52^{\circ} 17^{\prime} \mathrm{E}\right.$, mid-point of the pelagic longline gear) is in the proximity of the southwestern limit of the Exclusive Economic Zone of Reunion Island, France (Fig. 2). The research pelagic drifting longline used in this set consists of deep sections (12 hooks between floats, maximum fishing depth [MFD] 215-323 m), very deep sections (24 hooks between floats, MFD 439-534 m) and surface sections (six hooks between floats, MFD 67-146 m). The shark was caught on a very deep section of the gear by the fifth hook baited with squid, Illex argentinus (Castellanos, 1960), at the estimated depth 290-300 m. MFD and estimated hook depth were calculated using corrected catenary curve geometry (Bach et al. 2009) with COPAL software v. 2.5.3 (Bach et al. 2011), and adjusted using direct measurements of section mid-point depth with temperature-depth recorders (TDR).

Sea surface temperature (SST) measured during vertical profiling of the water column with TDR before and after the fishing operation ranged within 25.9-26. ${ }^{\circ} \mathrm{C}, \mathrm{T}{ }^{\circ} \mathrm{C}$ at a depth of $300 \mathrm{~m}$ varied from 15.4 to $16.1{ }^{\circ} \mathrm{C}$. Ocean floor topography 


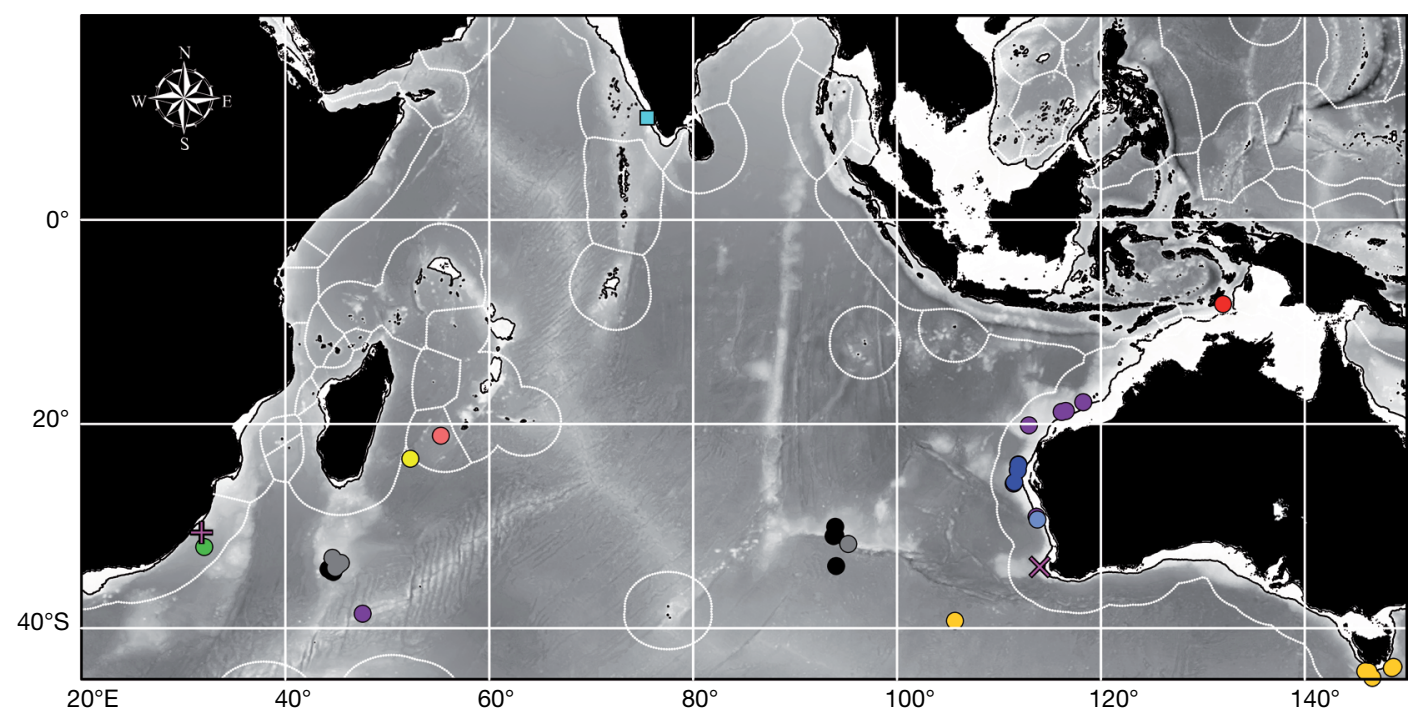

FIG. 2. - Geographic position of Zameus squamulosus (Günther, 1877) from the Indian Ocean (Table 2): Pelagic records: yellow dot (this study) and orange dots (CSIRO); Demersal records: black dots (YugNIRO, this study), grey dots ZM MGU (Scherbachev et al. 1982), pink dot (MNHN), purple dots (CSIRO), blue (AM), light blue (MV), green (Iziko SAM), red dot (IRD bottom survey), please note superposition of several CSIRO, AM and MV records; Sperm whale stomach records: straight cross is Bass et al. (1976) and oblique cross is WAM; Bright blue square is landing site recovery (Akhilesh et al. 2011). Approximate position of the 200-mile Exclusive Economic Zones (EEZs) of coastal states (dotted line) and $200 \mathrm{~m}$ isobath are shown. Coastline and bathymetry data are from GEBCO (2010), EEZs are from VLIZ (2011).

data taken from the GEBCO database (GEBCO 2010) suggests that the fishing gear was deployed and drifted over a deep-water canyon (bottom depths 5000-5400 m) surrounded by deep-water seamounts (minimum depth 3500-3800 m), and by an abyssal plain of 4500-4900 m deep.

The shark was frozen and stored for 30 days before examination. The specimen was deposited in the collections of the Muséum national d'Histoire naturelle, Paris (catalogue number MNHN 20120188).

Measurements were taken to the nearest $\mathrm{mm}$ following Bass et al. (1976) and Compagno (1984) approaches and expressed as percentage of TL. Total length used for calculation of body proportions was measured for "stretched" caudal fin as presented in Compagno (1984) in alternative to "natural" position as suggested by Bass et al. (1976). Denticles from left side of the trunk (Fig. 3A) were examined under a light microscope (Olympus SZ61 under $\times 45$ magnification) and photographed with digital camera Olympus SP510UZ resolution 7.1 Mpx.
Another eight specimens of this species were caught by demersal longlines during commercial fishing operations in the southern Indian Ocean in March-April 2008. Individuals were sampled and identified by S.T. Rebik as Scymnodon obscurus Vaillant, 1888 (a synonym of Zameus squamulosus) using keys in Compagno (1984) (Fig. 1B). Denticles from left side of the trunk were also photographed using a light microscope (Fig. 3B). Occurrence, fishing depth and some biological observations were recorded and used here to illustrate both spatial and vertical species distribution (Figs 2; 4).

One more individual (female, $710 \mathrm{~mm} \mathrm{TL}$ ) preserved in the MNHN collections (catalogue number MNHN 2007-1658, identified by B. Séret as S. obscurus) was caught on the slope of Reunion Island using a demersal longline baited with squid on 22 February 2005 by the commercial fishing vessel Ludo (Fig. 2).

The Indian Ocean area is considered here according to FAO definitions of fishing areas 51 and 57 , with its western border off South Africa at $30^{\circ} \mathrm{E}$ and eastern border off Southern Australia at $150^{\circ} \mathrm{E}$. 

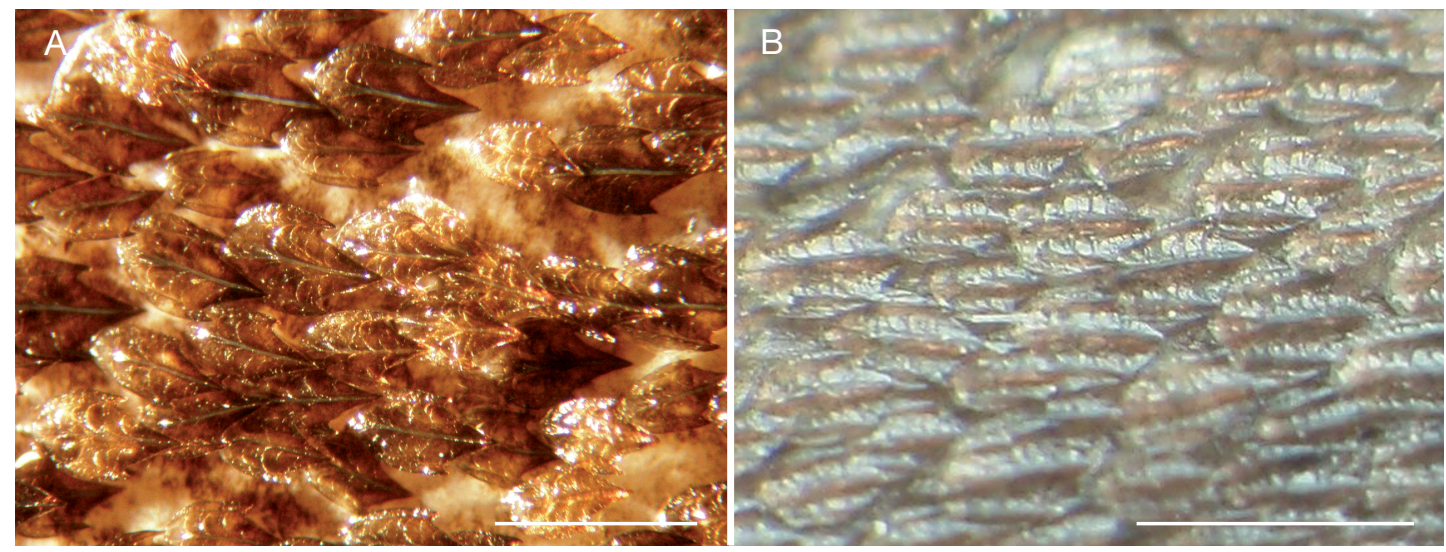

FIG. 3. - Dermal denticles from the trunk region of Zameus squamulosus (Günther, 1877) caught in the pelagic and demersal environment: A, MNHN 2012-0188, female, $676 \mathrm{~mm}$ TL; B, female from demersal zone of the southeastern Indian Ocean shown on the Figure 1B. Scale bar: $1 \mathrm{~mm}$.

\section{ABBREVIATIONS}

\section{Institutions, collector}

AM Australian Museum, Sydney;

NHMUK The Natural History Museum, London (formerly BMNH, British Museum of Natural History);

CSIRO CSIRO-Ichthyology Castray Esplanade, Hobart;

IRD Institut de Recherche pour le Développement;

Iziko SAM Iziko South African Museum - Fish collection, Cape Town;

MNHN Muséum national d'Histoire naturelle, Paris;

MV Museum Victoria Ichthyology, Melbourne;

STR S. T. Rebik collector;

WAM Western Australian Museum, Perth;

YugNIRO Southern Scientific Research Institute of Marine Fisheries and Oceanography;

$\mathrm{ZMH} \quad$ Biocenter Grindel und Zoological Museum, University of Hamburg, Hamburg;

ZM MGU Zoological Museum of the Moscow State University, Moscow.

\section{Databases, programs}

Discover Life An interactive encyclopedia of life. http:// www.discoverlife.org;

FishBase World Wide Web electronic publication. http://www.fishbase.org;

GBIF Global Biodiversity Information Facility. http://data.gbif.org;

ITIS Integrated Taxonomic Information System. http://www.itis.gov.
OBIS The Ocean Biogeographic Information System. http://www.iobis.org;

PROSPER Prospection et habitat des grands pélagiques de la ZEE de La Réunion;

WoRMS World Register of Marine Species http://www.marinespecies.org.

\section{Measurements}

FL fork lenght;

PP2 Prepelvic fin length;

SVL Snout-vent length;

TDR temperature-depth recorder. Model: SPT2T600-PI, NKE instrumentation, rue Gutenberg, Z.I. Kérandré, 56700, Hennebont, France;

TL total length.

\section{SYSTEMATIC ACCOUNT}

Family SOMNIOSIDAE Jordan, 1888

Genus Zameus Jordan \& Fowler, 1903

\section{Zameus squamulosus (Günther, 1877)}

(Figs 1; 3)

Synonyms: Centroscymnus obscurus Vaillant, 1888, Expéditions scientifiques du Travailleur et du Talisman pendant les années 1880, 1881, 1882, 1883. Poissons, 67-68, pl. 2, fig. 2a-e. Holotype: Muséum national d'Histoire naturelle, Paris, MNHN-84-388, 590 mm female, 'côtes du Soudan', 1400-1435 m. 
TABLE 1. - Total length and body proportions (in \% of total length sensu Compagno (1984) of Zameus squamulosus (Günther, 1877) from the southwestern Indian Ocean and from specimens collected in the Atlantic and Pacific. Measured dimensions are given following terminology of Compagno (2001), except for terms and measurements adopted from Bass et al. (1976) given in italics, and spine measurements adopted from Clarke, Irvine (2006), given in bold italics.

\begin{tabular}{|c|c|c|c|c|c|c|c|}
\hline Measurements & 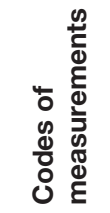 & 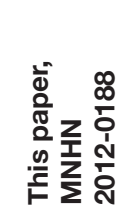 & 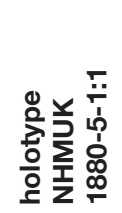 & 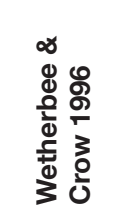 & 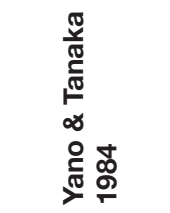 & 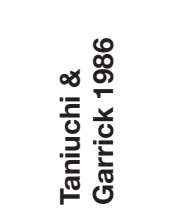 & 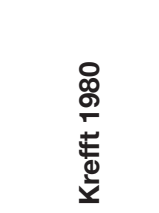 \\
\hline $\bar{N}$ & - & 1 & 1 & 1 & 12 & 4 & 3 \\
\hline Sex & - & 우 & 아 10101010 & 아 & $80^{\pi} 0^{\pi}, 4$ ๆ & $20^{x} 0^{x}, 2$ † & 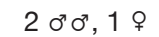 \\
\hline Maturity & - & $\begin{array}{c}\text { not } \\
\text { available }\end{array}$ & mature & mature & $\begin{array}{c}\text { not } \\
\text { available }\end{array}$ & $\begin{array}{c}\text { not } \\
\text { available }\end{array}$ & $\begin{array}{l}\sigma^{7} \text { mature, } \\
\text { on juv., }^{7} \text { juv }\end{array}$ \\
\hline Total length & TL & 672 & 670 & 786 & $263-634$ & $256-667$ & $316-493$ \\
\hline Prenarial length & PRN & 2.3 & 2.5 & 2.3 & $1.2-2.8$ & $1.6-2.1$ & $1.3-1.4$ \\
\hline Preorbital length & $\mathrm{POB}$ & 5.8 & 5.6 & 5.6 & $4.1-6.4$ & $4.6-6.6$ & - \\
\hline Prespiracular length & PSP & 11.4 & 11.2 & 11.1 & $10.0-12.8$ & $10.8-13.9$ & - \\
\hline Preoral length & POR & 8.6 & 7.6 & 7.5 & $7.0-10.7$ & $7.2-9.6$ & $7.8-9.0$ \\
\hline Prebranchial length & PG1 & 18.2 & 17.2 & 16.7 & $15.5-19.9$ & $16.9-20.5$ & - \\
\hline Head length & HDL & 21.9 & 21.2 & 20.8 & $20.1-23.7$ & $20.5-24.4$ & - \\
\hline Prepectoral fin length & PP1 & 23.0 & 21.0 & 21.1 & $20.8-24.1$ & $20.7-24.8$ & 22.6-23.7 \\
\hline Prepelvic fin length & PP2 & 61.4 & 59.3 & 60.6 & $55.7-61.0$ & $53.8-58.6$ & $57.6-58.3$ \\
\hline Snout-vent length & SVL & 68.4 & 63.7 & 65.0 & $59.9-65.9$ & - & - \\
\hline Pre-first dorsal fin length & PD1 & 40.5 & 35.4 & 41.4 & $39.5-43.5$ & $33.1-40.4$ & $40.8-42.9$ \\
\hline Pre-second dorsal fin length & PD2 & 68.0 & 62.1 & 68.3 & $64.8-69.7$ & $58.6-63.6$ & $65.2-66.8$ \\
\hline Precaudal fin length & PCL & 81.6 & 82.2 & 81.9 & $77.1-83.1$ & $75.0-81.3$ & $78.5-80.7$ \\
\hline $\begin{array}{l}\text { Distance from snout tip to lower } \\
\text { caudal origin }\end{array}$ & - & 79.9 & 78.1 & 79.1 & $75.4-80.4$ & $73.8-79.0$ & - \\
\hline $\begin{array}{l}\text { Interspace between 1st and } \\
2 \text { nd dorsal spines }\end{array}$ & - & 26.1 & - & 25.5 & $18.1-24.9$ & - & $19.4-22.4$ \\
\hline Dorsal-caudal fin space & DCS & 9.6 & 9.0 & 8.7 & $6.4-9.1$ & - & $9.7-10.0$ \\
\hline Pelvic fin-caudal fin space & PCA & 11.5 & - & 12.4 & $10.5-14.3$ & - & $10.7-12.9$ \\
\hline Pectoral fin - pelvic fin space & PPS & 32.1 & 30.1 & - & - & - & - \\
\hline $\begin{array}{l}\text { Distance between origins of pectoral } \\
\text { and pelvic fins }\end{array}$ & $\begin{array}{l}\mathrm{DPI}+ \\
\mathrm{DPO}\end{array}$ & 38.6 & - & 34.8 & 31.7-39.5 & - & $32.2-34.6$ \\
\hline Internarial space & INW & 4.1 & 3.3 & 3.7 & $3.3-4.8$ & $3.0-5.5$ & $4.3-4.6$ \\
\hline $\begin{array}{l}\text { Distance between inner corner of } \\
\text { preoral clefts }\end{array}$ & - & 4.0 & - & 3.9 & $4.1-6.1$ & - & - \\
\hline Mouth width & MOW & 7.0 & 7.1 & 7.1 & 7.3-9.9 & $7.0-8.8$ & $7.7-7.8$ \\
\hline First gill slit heigth & GS1 & 1.6 & 1.5 & 1.7 & $0.9-2.1$ & $1.3-1.8$ & $1.3-1.7$ \\
\hline Fifth gill slit heigth & GS5 & 1.8 & 1.6 & 1.8 & $1.1-2.1$ & $1.5-2.1$ & $1.7-2.0$ \\
\hline Eye length & EYL & 4.9 & 4.1 & 3.7 & $4.2-6.1$ & $4.0-5.9$ & $5.0-5.7$ \\
\hline Interorbital space & INO & 7.4 & 7.8 & 6.8 & $8.2-11.1$ & - & - \\
\hline First dorsal fin anterior margin & D1A & 8.8 & - & - & - & - & - \\
\hline First dorsal fin base & D1B & 6.2 & 8.5 & 4.1 & 3.3-4.4 & $5.8-8.4$ & $2.9-3.9$ \\
\hline First dorsal fin posterior margin & D1P & 3.1 & - & 3.7 & $2.8-4.7$ & $4.1-5.3$ & - \\
\hline First dorsal fin inner margin & D1I & 5.1 & 4.5 & - & - & - & - \\
\hline $\begin{array}{l}\text { First dorsal fin external spine } \\
\text { length }\end{array}$ & D1ESL & 0.6 & 1.5 & 0.7 & $0.3-1.1$ & - & $0.2-0.4$ \\
\hline First dorsal fin height & $\mathrm{D} 1 \mathrm{H}$ & 2.4 & 2.7 & 2.9 & $2.0-3.5$ & $2.2-2.9$ & $2.1-2.2$ \\
\hline Second dorsal fin anterior margin & D2A & 7.3 & - & - & - & - & - \\
\hline Second dorsal fin base & D2B & 6.6 & 10.6 & 5.9 & 4.6-7.6 & $7.5-9.1$ & $5.0-5.3$ \\
\hline Second dorsal fin posterior margin & D2P & 6.5 & - & 6.6 & 5.3-7.9 & $4.4-5.4$ & - \\
\hline Second dorsal fin inner margin & D2I & 5.3 & 4.9 & - & - & - & - \\
\hline
\end{tabular}


TABLE 1. - Continuation.

\begin{tabular}{|c|c|c|c|c|c|c|c|}
\hline Measurements & 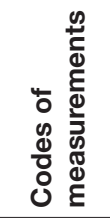 & 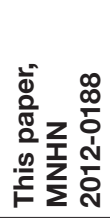 & 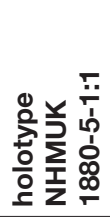 & 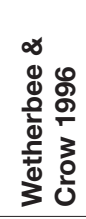 & 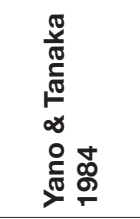 & 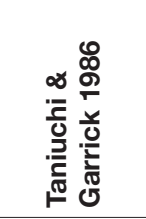 & 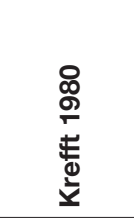 \\
\hline $\begin{array}{l}\text { Second dorsal fin external spine } \\
\text { length }\end{array}$ & D2ESL & 0.3 & 1.5 & 0.5 & $0.2-1.1$ & - & $0.3-0.4$ \\
\hline Second dorsal fin height & $\mathrm{D} 2 \mathrm{H}$ & 3.1 & 3.7 & 3.7 & $3.0-3.8$ & $2.8-3.5$ & $3.0-3.6$ \\
\hline Pectoral fin anterior margin & P1A & 11.5 & 11.6 & 10.4 & $9.5-12.5$ & $10.5-12.2$ & - \\
\hline Pectoral fin posterior margin & P1P & 5.2 & - & 5.2 & $4.3-6.3$ & - & - \\
\hline Pelvic fin anterior margin & P2A & 6.6 & 7.0 & 6.1 & $4.5-8.2$ & $5.8-8.3$ & - \\
\hline Pelvic fin height & $\mathrm{P} 2 \mathrm{H}$ & 3.5 & - & 3.1 & 2.8-4.1 & - & - \\
\hline Pelvic fin posterior margin & P2P & 7.6 & 6.9 & - & - & - & - \\
\hline Dorsal caudal fin margin & CDM & 18.4 & 19.1 & 17.6 & $17.3-23.2$ & $19.6-24.2$ & $20.1-20.5$ \\
\hline Preventral caudal fin margin & CPV & 11.3 & 12.7 & 11.2 & $10.2-13.5$ & $12.2-13.5$ & $12.7-12.8$ \\
\hline Depth of caudal fin notch & CST & 2.9 & - & 2.2 & $2.7-4.3$ & - & - \\
\hline Trunk width at pectoral origin & - & 10.0 & - & 10.4 & $11.0-15.3$ & $11.3-12.5$ & 11.4-12.6 \\
\hline Head height & $\mathrm{HDH}$ & 12.5 & - & 7.6 & $8.8-13.4$ & $8.6-10.2$ & $10.6-11.2$ \\
\hline
\end{tabular}

Other combinations: Scymnodon squamulosus (Regan, 1908), Scymnodon obscurus Bigelow and Schroeder (1957).

Material EXAMINED. - Southwestern Indian Ocean, $23^{\circ} 17^{\prime}$ S, 52¹7'E, 25.V.2011, ᄋ, $672 \mathrm{~mm}$ TL, MNHN 2012-0188. - Japan, off Imosiina, holotype of Centrophorus squamulosus Günther, 1877, adult $\$, 670 \mathrm{~mm}$ TL, NHMUK 1880-5-1:1. — Broken Ridge, southeastern In-

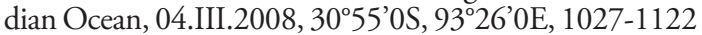
$\mathrm{m}$, , $830 \mathrm{~mm} \mathrm{TL}$ (coll. STR); 3055'0S, 9402'0 E, 1138$1152 \mathrm{~m}, 05$. III.2008, unsexed, $600 \mathrm{~mm}$ TL (coll. STR); $30^{\circ} 59^{\prime} 0 \mathrm{~S}, 93^{\circ} 47^{\prime} 0 \mathrm{E}, 1048-1134 \mathrm{~m}, 12 . \mathrm{III} .2008$, 웅, $730 \mathrm{~mm}$ TL, unsexed, $810 \mathrm{~mm}$ TL (coll. STR); $30^{\circ} 04^{\prime} 0 \mathrm{~S}$, 935'드, 1062-1169 m, 17.III.2008, gravid $9,900 \mathrm{~mm}$ TL (coll. STR). - Southwest Indian Ocean Ridge, $34^{\circ} 13^{\prime} 0 \mathrm{~S}, 44^{\circ} 14^{\prime} 0 \mathrm{E}, 1414-1456 \mathrm{~m}, 04 . \mathrm{IV} .2008$, un-

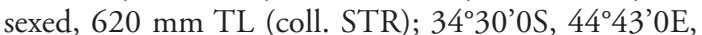
1278-1556 m, 09.IV.2008, ơ, 530 mm TL (coll. STR); $34^{\circ} 26^{\prime} 0 \mathrm{~S}, 44^{\circ} 33^{\prime} 0 \mathrm{E}, 1450-1528 \mathrm{~m}, 21 . \mathrm{IV} .2008$, unsexed, $830 \mathrm{~mm}$ TL (coll. STR).

Distribution. - Worldwide over continental slopes and undersea ridges in tropical and temperate waters.

\section{DESCRIPTION}

Individual caught in pelagic environment (MNHN 2012-0188) is a medium-sized, black-coloured shark with bright green eyes. It was alive at the time it was taken onboard but quickly died afterwards. Body proportions of our specimen are shown in Table 1. Dental formula: 27-27/21-21.
Our specimen well corresponds to the original description given by Günther (1877) and later by Yano \& Tanaka (1984). Body measurements are within the ranges presented in other studies, except PP2, SVL (slightly higher than reported earlier) and trunk width (slightly lower) (Table 1). The latter could be explained by post-defrosting deformation.

\section{DISCUSSION}

To date, 10 individuals of this species are reported in the literature from the Indian Ocean region (Table 2). First record by Bass et al. (1976) who reported four semi-digested individuals taken from the stomach of a sperm whale Physeter macrocephalus harpooned $112 \mathrm{~km}$ southeast of Durban (Fig. 2). Consequently no exact data on both shark location and habitat depth were recovered. Another five individuals were caught by bottom trawls along deep-water ridges of the southern tropical Indian Ocean during Soviet research cruises in 1976-79 (Scherbachev et al. 1982). One more individual was recently recovered at the landing site in Cochin Fishing Harbour (India), but precise capture position is apparently unknown (Akhilesh et al. 2011) (Fig. 2; Table 2). 


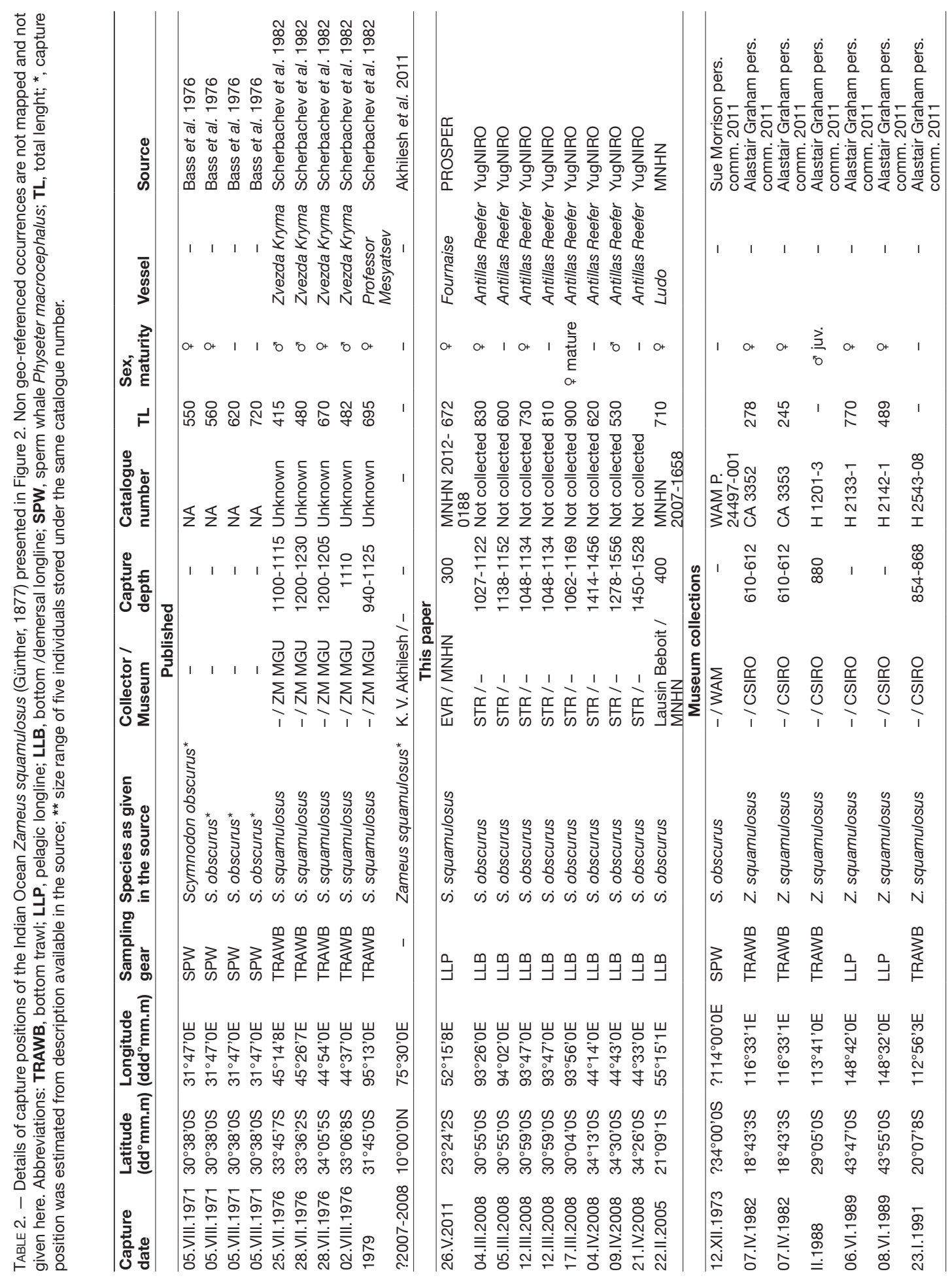




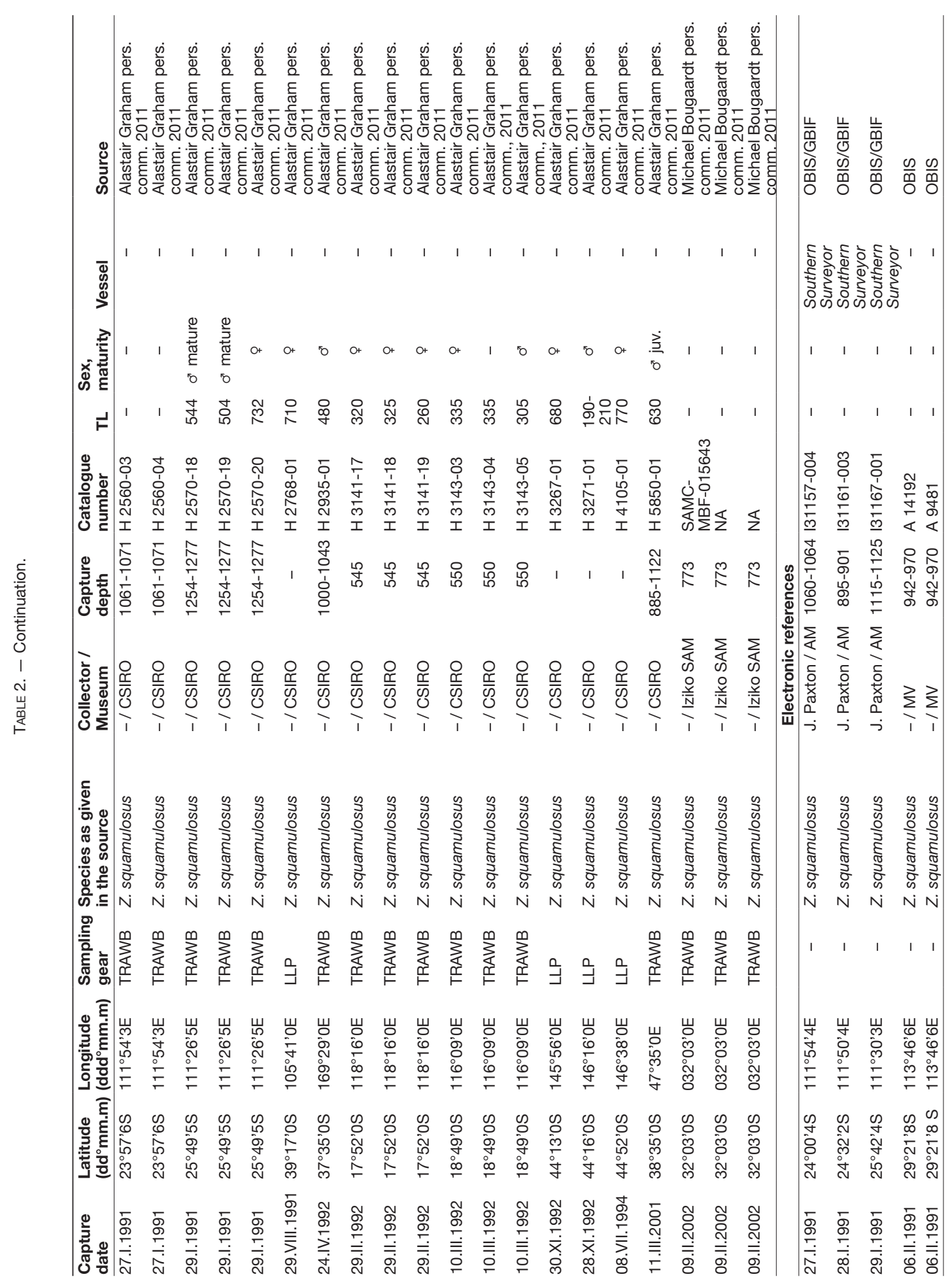




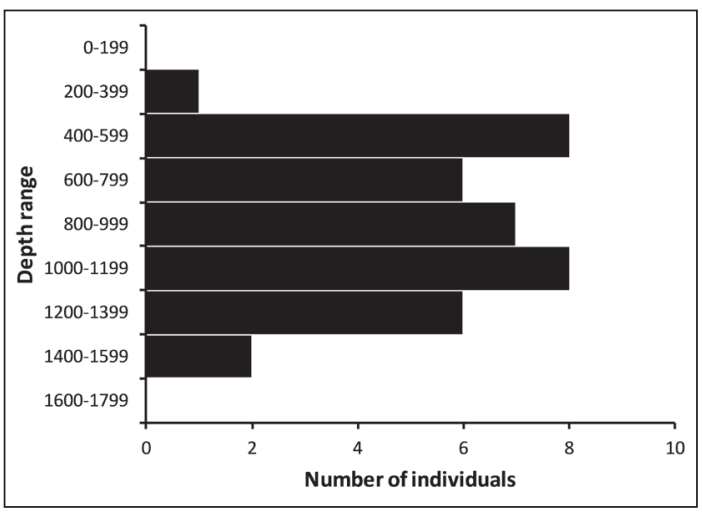

FIG. 4. - Depth distribution of Zameus squamulosus (Günther, 1877 ) with known capture depth recorded in the Indian Ocean $(n=42)$. For non-precise depth of capture, shallower depth in the range of values was used.

Last \& Stevens (2009) mentioned captures of Z. squamulosus along the shelf of Western Australia by trawls and off Southern Australia by Japanese longliners in pelagic waters. Numbers of individuals caught and positions of capture were not presented in the source.

Similarly White et al. (2006) reported occurrences of this species in Indonesia (off western Java).

Direct correspondence with museums allowed us to obtain data on 35 records from the Indian Ocean (CSIRO, 31 ind.; Iziko SAM, 3 ind.; WAM, 1 ind.). Among these records twelve originated from pelagic gears, 22 were caught in the demersal environment, and one (WAM) was found in the stomach of a sperm whale (Fig. 2; Table 2).

Online resources were assumed to be a handy tool for fast and easy access to taxonomic and biogeographic information (Costello \& Berghe 2006). Indeed internet portals appeared to be very useful to find occurrences, which otherwise would remains unknown/inaccessible for us. However we found that online portals handling taxonomic and fish biodiversity information (Discover Life, FishBase, GBIF, ITIS, OBIS, WoRMS) often maintain outdated taxonomic data. The species in question was commonly found either under synonymised names as $S$. squamulosus and S. obscurus or both were considered as separate valid species (Vanden Berghe 2007; Appeltans et al. 2011; Froese \& Pauly
2011; GBIF 2011; Discover Life 2012; ITIS 2013). To some extent such a situation can be explained by the fact that the taxonomic status of this species has only been recently established (McEachran \& Fechhelm 1998; Compagno 2003; Last \& Stevens 2009).

Despite taxonomic uncertainties, we traced the number of unpublished records. Most of them originated from museum collections already available to us by direct correspondence (CSIRO, Iziko SAM). Additional records are demersal catches from Western Australia (OBIS: AM, 3 ind.; and MV 2 ind.) and southern Indonesia (off Tanimbar Islands) (OBIS, IRD KARUBAR cruise, 2 ind.) (Vanden Berghe 2007) (Fig. 2; Table 2).

The FishBase map (Froese \& Pauly 2011) shows more Indian Ocean records for this species (both identified as $S$. obscurus and $Z$. squamulosus), however, links to published references or museum collections are not always evident for several mapped points, therefore their validity cannot be confirmed. Furthermore, some records of $S$. obscurus traced through FishBase and GBIF to specimens from collections of ZMH (e.g., ZMH 112266) should be attributed to other species and/or sampled in other oceans (RalfThiel [Curator Ichthyology, Biocenter Grindel und Zoological Museum University of Hamburg] pers. comm., 2011). In addition, capture positions provided by GBIF and OBIS for the same individuals (inventory numbers) from the collections of the Australian Museum and the Museum Victoria were different. Therefore, the reliability of online data sources for reporting of rare species distribution is still questionable as suggested by Eschmeyer \& Fricke (2012).

Our records and earlier collected data show that $Z$. squamulosus is distributed within the subtropical area of the southern Indian Ocean from the African to the Australian coasts (Fig. 2). Only few records are from the tropics and only one individual is from the northern hemisphere (Fig. 2). Capture positions are usually associated with continental slopes and mid-ocean undersea ridges.

The majority of Indian Ocean records except our pelagic individual and twelve individuals from CSIRO were caught in demersal environment. Most of the fishes were taken between 400 and 
$1400 \mathrm{~m}$ depth; peak of occurrences is within the 1000-1200 m range (Fig. 4). Such a pattern suggests a benthopelagic life style of $Z$. squamulosus with regular excursions from the benthic to pelagic waters within the upper bathyal habitat.

Meanwhile, our pelagic capture reported here is not an exception. In the Atlantic and Pacific Ocean $Z$. squamulosus is considered as a pelagic species in some areas (Yano \& Tanaka 1984; Compagno 1984). Numbers of pelagic records of this species have increased exponentially worldwide from single individuals some decades ago (Krefft 1980; Wetherbee \& Crow 1996) to several dozens of individuals reported annually in recent years (Matsuhita \& Matsunaga 2002; Dai et al. 2009; Zhu et al. 2012). Last \& Stevens (2009) stated that pelagic records are more common than benthic ones off southern Australia. Such an increased number of recent occurrences cannot be explained only by expanded scientific observers' coverage of fishing operations and improved identification of specimens caught. The archive of high-quality long-term research data collected with pelagic longlines over all the Indian Ocean (Romanov et al. 2006) contains no records of this species in the pelagic environment from 1961 to 1989. We may be evidencing a long-term increase in abundance of this species similarly with other mid-sized oceanic predators like crocodile shark (Romanov et al. 2008), bramids and gempylids (Polovina et al. 2009) in response to the depleted state of large-sized predators or competitors (mesopredator-release effect)(Baum \& Worm 2009; Ferretti et al. 2010).

At the same time, both pelagic and benthic records of $Z$. squamulosus are still rare over the vast area of the central and western Indian Ocean. Pelagic longline fisheries covering most of the surface of the tropical and temperate Indian Ocean developed an average fishing effort of almost 700 million hooks annually from 2000 to 2010 (Fonteneau 2010; Fonteneau pers. comm., 2012). Only thirteen pelagic individuals of this species recorded during the history of regional fisheries observations under such significant fishing effort suggests that epipelagic excursions should be considered rather as an exception than common habit.
The range of the TL of the Indian Ocean individuals reported in this note is within 415 and $900 \mathrm{~mm}$. Four of eight individuals analysed in the field by STR exceeded the maximum reported length (TL) of $786 \mathrm{~mm}$ (Wetherbee \& Crow 1996), and one exceeds the maximum length (TL) suggested by Last \& Stevens (1994, 2009) (Tables 1; 2). Both sexes were present in catches; some individuals were mature. One gravid female $(\mathrm{TL}=900 \mathrm{~mm})$ caught on 17 March 2008 (Table 2) had two embryos at an advanced stage of development. Overall Indian Ocean records show dominance of females: 1.9:1.0, which however non-significantly deviate from 1:1 sex ratio $\left(\chi^{2}=3.125, p=0.0771\right)$.

The rarity of this species is an apparent consequence of a relatively low fishing effort within its principal depth distribution range and the scarcity of scientific observations in deep-water fisheries. However low fishing pressure is rather beneficial for the conservation of this species taking into account both the high longevity and slow reproduction rate characteristic of most deep-water chondrichthyans (Musick \& Bonfil 2005).

\section{Acknowledgements}

We are thankful to the captain and the crew of F/V Fournaise for proper handling of our specimen during fishing operation and overall assistance during the research cruise. We acknowledge kind permission of the Government of Namibia to use occurrence data collected onboard Namibian-flagged F/V Antillas Reefer. Thanks are due to the captain and crew of F/V Antillas Reefer for their help rendered to STR during sampling and photographing. Our thanks to Mr Lausin Beboit, captain of F/V Ludo, for the collection and preservation of an individual of $Z$. squamulosus (MNHN 2007-1658).

Contributions of referees: S. Amir, P. Kyne and A. Ohler improved clarity and completeness of the paper.

Special thanks are due to Clément Martineau (ESA, Angers) for his help in microscopic photography of scales.

Alastair Graham (CSIRO), Sue Morrison (WAM), Michael Bougaardt (Iziko SAM), and Roger Bills (SAIAB, Grahamstown) provided data for specimens 
stored in their respective museums. Particular thanks are offered to Dr Ralf Thiel, curator Ichthyology in $\mathrm{ZMH}$, for precisions with species attribution and capture positions of sharks of the genus Scymnodon stored at $\mathrm{ZMH}$ collection.

Alain Fonteneau provided estimates of international pelagic longline effort in the Indian Ocean during 2006-2010.

We appreciate assistance with the English of the manuscript provided by Dr Marcelo de Carvalho and by Mr Alan Sharp.

PROSPER Project is funded by the Fonds Européen pour la Pêche (FEP).

\section{REFERENCES}

Akhilesh K. V., Ganga U., Pillai N. G. K., VivekananDAN E., BineEsh K. K., Shanis C. P. R. \& Hashim M. 2011. - Deep-sea fishing for chondrichthyan resources and sustainability concerns - a case study from southwest coast of India. Indian Journal of Geo-Marine Sciences 40 (3): 347-355.

Appeltans W., Bouchet P., Boxshall G. A., Fauchald K., Gordon D. P., Hoeksema B. W., Poore G. C. B., Van Soest R. W. M., StÖHr S., Walter T. C. \& Costello M. J. (eds) 2011. - World Register of Marine Species (WoRMS). http://www.marinespecies. org, accessed on 4 June 2011.

Bach P., Gaertner D., Menkes C., Romanov E. \& Travassos P. 2009. - Effects of the gear deployment strategy and current shear on pelagic longline shoaling. Fisheries Research 95: 55-64.

BACH P., ROMANOV E. \& GAERTNER D. 2011. — COPAL (Comportement de la Palangre). Longline behaviour modelling software. Version 2.5.3. IRD.

Bass A. J., D'Aubrey J. D. \& Kistnasamy N. 1976. Sharks of the East Coast of Southern Africa. VI. The Families Oxynotidae, Squalidae, Dalatiidae, and Echinorhinidae. Investigational Report 45. South African Association for Marine Biological Research, Oceanographic Research Institute, Durban, 103 p.

BAUM J. K. \& WORM B. 2009. — Cascading top-down effects of changing oceanic predator abundances. Journal of Animal Ecology 76: 480-489. http://dx.doi. org/10.1111/j.1365-2656.2009.01531.x

Bigelow H. B. \& Schroeder W. C. 1957.—A study of the sharks of the suborder Squaloidea. Bulletin of the Museum of Comparative Zoology at Harvard College, 117(1): 1-150.

Burgess G. H. \& ChIN A. 2006. - Zameus squamulosus, in IUCN, IUCN Red List of Threatened Species. Version 2012.1. http://www.iucnredlist.org. Downloaded on 14 August 2012.

Clarke M. W. \& Irvine S. B. 2006. - Terminology for the ageing of chondrichthyan fish using dorsal-fin spines. Environmental Biology of Fishes 77: 273-277.

Compagno L. J. V. 1984. - FAO species catalogue. Vol. 4. Sharks of the world. An annotated and illustrated catalogue of sharks species known to date. Part 1. Hexanchiformes to Lamniformes. FAO Fisheries Synopsis 125 (4): 1-249.

Compagno L. J. V. 2001. - Sharks of the world. An annotated and illustrated catalogue of shark species known to date. Volume 2. Bullhead, mackerel and carpet sharks (Heterodontiformes, Lamniformes and Orectolobiformes). FAO Species Catalogue for Fishery Purposes. No. 1, Vol. 2. FAO, Rome. 269 p.

Compagno L. J. V. 2003. - Sharks, in CARPENTER K. E. (ed.), The living marine resources of the western central Atlantic. Volume 1: Introduction, molluscs, crustaceans, hagfishes, sharks, batoid fishes, and chimaeras. FAO Species Identification Guide for Fishery Purposes and American Society of Ichthyologists and Herpetologists Special Publication 5. FAO, Rome, 357-505.

Costello M. J. \& Berghe E. V. 2006. - Ocean biodiversity informatics: a new era in marine biology research and management. Marine Ecology Progress Series 316: 203-214.

DAi X. J., Zheng Y., JiAng R. L. \& Xu L. X. 2009. Shark by-catch observation in ICCAT waters by Chinese longline observers in 2007. Collective Volume of Scientific Papers ICCAT 64 (5): 1741-1745. SCRS/2008/156.

DisCOVER Life 2012. - http://www.discoverlife.org. Accessed on 29.02.2012.

ESCHMEYER W. N. \& Fricke R. (eds) 2012. — Catalog of fishes electronic version (12.02.2012). http:// research.calacademy.org/research/ichthyology/catalog/ fishcatmain.asp

Ferretti F., Worm B., Britten G. L., Heithaus M. R. \& LOTZE H. K. 2010. - Patterns and ecosystem consequences of shark declines in the ocean. Ecology Letters 13: 1055-1071. http://dx.doi.org/10.1111/ j.1461-0248.2010.01489.x

FonTENEAU A. 2010. - Atlas des pêcheries thonières de l'océan Indien. Atlas of Indian Ocean Tuna Fisheries. IRD éditions, Marseille, $189 \mathrm{p}$.

Froese R. \& Pauly D. (eds) 2011. — FishBase. World Wide Web electronic publication. www.fishbase.org, version (02.2011).

GBIF 2011. - Global Biodiversity Information Facility (GBIF) Data Portal. http://data.gbif.org. Accessed 22.06.2011.

GEBCO 2010. - The GEBCO_08 Grid, version 20100927. http://www.gebco.net

GÜNTHER A. 1877. - Preliminary notes on new fishes collected in Japan during the expedition of H.M.S. 
Challenger. Annals and Magazine of Natural History (series 4) 20 (119): 433-446.

ITIS, 2013. - Integrated Taxonomic Information System (ITIS). Retrieved 24.02.2013, from the http:// www.itis.gov.

JoRDAN D. S. 1888. - A Manual of the Vertebrate Animals of the Northern United States. 5th edition. A. C. McClurg and Company, Chicago, 375 p.

JordAN D. S. \& FowLER H. W. 1903. - A review of the elasmobranchiate fishes of Japan. Proceedings of the United States National Museum 26 (1324): 593-674.

KREFFT G. 1980. - Results of the research cruises of FRV Walther Herwig to South America. 53. Sharks from the pelagic trawl catches obtained during Atlantic transects, including some specimens from other cruises. Archiv für Fischereiwissenschaft 30: 1-16.

LAST P. R. \& STEVENS J. D. 1994. - Sharks and Rays of Australia. CSIRO, Melbourne, i-vi, 513 p., LXXXIV colour pls.

Last P. R. \& Stevens J. D. 2009. - Sharks and Rays of Australia. 2nd edition. CSIRO, Melbourne, i-vii, 644 p., XCI colour pls.

Matsushita Y. \& Matsunaga H. 2002. - Species composition and cpue of pelagic sharks observed by japanese observers for tuna longline fisheries in the Atlantic Ocean. Collective Volume of Scientific Papers ICCAT 54 (4): 1371-1380. SCRS/2001/085.

MCEACHRAn J. D. \& FeCHHELM J. D. 1998. — Fishes of the Gulf of Mexico. Volume 1: Myxiniformes to Gasterosteiformes. University of Texas Press, Austin, $1112 \mathrm{p}$.

Musick J. A. \& Bonfil R. 2005. - Management techniques for elasmobranch fisheries. FAO Fisheries Technical Paper 474: 251p.

Polovina J. J., AbeCASSIS M., Howell E. A. \& WoOdWORTH P. 2009. - Increases in the relative abundance of mid-trophic level fishes concurrent with declines in apex predators in the subtropical North Pacific, 1996-2006. Fishery Bulletin 107 (4): 523-531.

REgAN, C. T. 1908. - A synopsis of the sharks of the family Squalidae. Annals and Magazine of Natural History (Series 8), 2(7): 39-57.

Romanov E. V., SaKagaWa G., Marsac F. \& Romanova N. 2006. - Historical database on Soviet tuna longline tuna research in the Indian and Atlantic oceans (first results of YugNIRO-NMFS data rescue project). Paper presented at the eighth session of the IOTC working party on tropical tunas. Seychelles, 24-28 July, 2006. IOTC-2006-WPTT-10, 32 p.
Romanov E. V., Ward P., LeVesque J. C. \& LAWRENCE E. 2008. - Preliminary analysis of crocodile shark (Pseudocarcharias kamoharai) distribution and abundance trends in pelagic longline fisheries. Paper presented at the IOTC Working Party on Ecosystems and Bycatch (WPEB) Bangkok, Thailand 20-22 October, 2008. IOTC-2008-WPEB-09. 29 p.

Scherbachev Y. N., Dolganov V. N. \& Timokhin I. G. 1982. - Deep-water cartilaginous fishes (Chondrichthyes) from southern hemisphere waters / Glubokovodnye khryashchevye ryby (Chondrichthyes) iz vod yuzhnogo polushariya, in Poorly Studied Fishes of the Open Ocean / Maloizuchennye ryby otkrytogo okeana. Shirshov Institute of Oceanology, Moscow: 6-24 (in Russian).

TANiUChi T. \& GARRICK J. A. F. 1986. - A new species of Scymnodalatias from the southern oceans, and comment on other squaliform sharks. Japanese Journal of Ichthyology 33: 119-134.

Vanden Berghe E. (ed.) 2007. - The Ocean Biogeographic Information System (OBIS): web pages. Available on http://www.iobis.org. Consulted on 4 June 2011.

VAILlanT L. L. 1888. - Expéditions scientifiques du Travailleur et $d u$ Talisman pendant les années 1880, 1881, 1882, 1883. Poissons. Masson, Paris, 406 p., $28 \mathrm{pls}$.

VlaAms InstituUt Voor de Zee (VLIZ) 2011. Maritime Boundaries Geodatabase, version 6.1. http://www.vliz.be/vmdcdata/marbound. Accessed on 23 June 2011.

Wetherbee B. M. \& Crow G. L. 1996. — First record of the squaloid shark Scymnodon squamulosus from the Hawaiian islands. Ichthyological Research 43: 334-339.

White W. T., Last P. R., Stevens J. D., Yearsley G. K., FAHMi \& DHARMADi 2006. - Economically important sharks and rays of Indonesia. ACIAR monograph series 124. Australian Centre for International Agricultural Research, Canberra, $329 \mathrm{p}$.

Yano K. \& TANaKa S. 1984. - Review of the deep sea squaloid shark genus Scymnodon of Japan, with a description of a new species. Japanese Journal of Ichthyology 30: 341-350.

Zhu J., Xu L., DAi X., Chen X. \& Chen Y. 2012. Comparative analysis of depth distribution for seventeen large pelagic fish species captured in a longline fishery in the central-eastern Pacific Ocean. Scientia Marina 76 (1): 149-157. http://dx.doi.org/10.3989/ scimar.03379.16C 